\title{
Article \\ The Effect of High-Pressure Treatment and Skimming on Caprine Milk Proteins
}

\author{
Katarzyna Kiełczewska $^{1} \mathbb{D}$, Aneta Dąbrowska ${ }^{1} \mathbb{D}$, Agnieszka Jankowska $^{2} \mathbb{D}$, Maria Wachowska $^{3} \mathbb{D}$ \\ and Jarosław Kowalik 1,*D
}

1 Department of Dairy Science and Quality Management, Faculty of Food Sciences, University of Warmia and Mazury in Olsztyn, Oczapowskiego 7, 10-719 Olsztyn, Poland; kaka@uwm.edu.pl (K.K.); anetazj@uwm.edu.pl (A.D.)

2 Department of Industrial and Food Microbiology, Faculty of Food Sciences, University of Warmia and Mazury in Olsztyn, Heweliusza 1, 10-718 Olsztyn, Poland; agajan@uwm.edu.pl

3 Department of Process Engineering, Equipment and Food Biotechnology, Faculty of Food Sciences, University of Warmia and Mazury in Olsztyn, Heweliusza 1, 10-718 Olsztyn, Poland; mari@uwm.edu.pl

* Correspondence: j.kowalik@uwm.edu.pl

Citation: Kiełczewska, K.;

Dąbrowska, A.; Jankowska, A.;

Wachowska, M.; Kowalik, J. The Effect of High-Pressure Treatment and Skimming on Caprine Milk Proteins. Appl. Sci. 2021, 11, 5982. https://doi.org/10.3390/app11135982

Academic Editor: Anabela

Raymundo

Received: 28 May 2021

Accepted: 24 June 2021

Published: 27 June 2021

Publisher's Note: MDPI stays neutral with regard to jurisdictional claims in published maps and institutional affiliations.

Copyright: (c) 2021 by the authors. Licensee MDPI, Basel, Switzerland. This article is an open access article distributed under the terms and conditions of the Creative Commons Attribution (CC BY) license (https:// creativecommons.org/licenses/by/ $4.0 /)$.

\begin{abstract}
Background: Proteins are susceptible to HP-treatment and there is a need to determine the applicability of HP-treatment in dairy production. The aim of this study was to determine the effect of HP-treatment at $200-500 \mathrm{MPa}\left(\mathrm{t}_{\text {const. }}=10 \mathrm{~min} ; \mathrm{T}_{\text {const. }}=20^{\circ} \mathrm{C}\right.$ ) and skimming of HP-treated milk on the content of nitrogen compounds and protein composition of caprine milk. Methods: The content of nitrogen (total, non-casein, non-protein) was determined using the Kjeldahl method. Casein fractions and whey proteins were separated using SDS-PAGE electrophoresis. Color parameters were measured in the CIELAB color space. Results: HP-treatment decreased $(p<0.05)$ the content of non-casein nitrogen and soluble whey proteins. Skimming decreased the content of nitrogen compounds, and the noted decrease was more pronounced in HP-treated milk. Pressure and skimming had no influence on the proportions of $\alpha-, \beta-, \mathrm{k}$-casein, $\beta$-lactoglobulin and $\alpha$-lactalbumin. Total color difference $(\Delta \mathrm{E})$ increased with a rise in pressure, particularly in skim milk. Conclusion: HP-treatment led to a loss of protein solubility at $\mathrm{pH} 4.6$ in caprine milk. In HP-treated milk, skimming did not induce changes in protein composition, despite a decrease in the content of nitrogen compounds after the separation of the cream layer. Higher values of $\Delta \mathrm{E}$ in skim milk than in whole milk point to changes in colloidal phase components.
\end{abstract}

Keywords: caprine milk; high-pressure treatment; nitrogen compounds; protein profile

\section{Introduction}

Proteins are susceptible to the influence of high pressure and this determines the applicability of high-pressure treatment in dairy production [1-5]. High-pressure treatment weakens hydrophobic and electrostatic interactions, and it strengthens or weakens hydrogen bonds, depending on the applied pressure. Hydrogen bonds are damaged under exposure to $\geq 700 \mathrm{MPa}$. Chemical bonds can be arranged in the following descending order based on their sensitivity to high pressure: hydrophobic interactions > electrostatic interactions $>$ hydrogen bonds $>$ covalent bonds. High-pressure treatment affects mainly quaternary (hydrophobic and non-covalent interactions), tertiary (ionic and hydrophobic interactions) and secondary protein structures (intra- and intermolecular hydrogen bonds). Exposure to pressure higher than $200 \mathrm{MPa}$ leads to the unfolding and reassociation of polypeptide chains. The pressure-resistant properties of proteins with a secondary structure ( $\alpha$-helices or $\beta$-sheets) are determined mainly by the presence of hydrogen bonds in molecular conformations [2-4,6-8].

High-pressure treatment induces the following changes in milk proteins: (1) the size of casein micelles changes [1,6,9-12]; (2) the proportions of soluble casein fractions 
increase in the following order: $\kappa \sim \beta>\alpha_{\mathrm{s} 1}>\alpha_{\mathrm{s} 2}[3,13,14]$; (3) the soluble form of calcium and phosphorus content of milk increase $[3,11,13,14]$; (4) whey proteins are denatured in the following order: lactoferrin $>\beta$-lactoglobulin $>$ immunoglobulins $>$ serum albumin $>\alpha$-lactalbumin [1,15]; and (5) milk proteins interact with milk fat globule membrane components [16].

Pressure-induced changes in protein structure influence the functional attributes of proteins, such as the ability to stabilize emulsions, bind water, and form gels. These changes are particularly important in the production of emulsions, ripened cheese, cottage cheese, and fermented milk products (such as yogurt), where the chemical, functional, and nutritional properties of proteins play a pivotal role [2-4].

Caprine milk casein is characterized by a higher content of $\beta$-casein and $\kappa$-casein, a lower content of $\alpha$-casein, in particular $\alpha_{\mathrm{s} 1}$-casein, in comparison with cow's milk [17-19]. Pressure-induced changes in milk proteins appear to be a crucial process in caprine milk. Caprine milk is more abundant in soluble casein than cow's milk [18], and $\beta$ casein in caprine milk is also dissociated under exposure to pressure or low temperature. The low hydration of casein micelles combined with the high content of ionized calcium and low citrate content contribute to the low colloidal stability of caprine milk $[17,18]$. High-pressure treatment induces the denaturation of caprine $\beta-\mathrm{Lg}$, enhances protein retention in the curd [20,21], and increases the content of non-soluble minerals and proteins in caprine milk [13].

High-pressure treatment is applied in the food processing industry to prolong the shelf life of raw materials and food products. High-pressure technology offers an alternative to thermal preservation, pasteurization, and sterilization in dairy production, and it enables the development of novel products with desirable textures, flavors, and functional properties [2-5]. Most research studies investigating the effects of high-pressure treatment on proteins were conducted on cow's milk, whereas caprine milk proteins attracted less interest $[3,11,13,20]$.

The aim of this study was to determine the effect of high-pressure treatment and skimming of HP-treated milk on the content of nitrogen compounds, protein composition, and color of caprine milk.

\section{Materials and Methods}

\subsection{Research Materials}

Raw milk for the experiment was obtained from Polish White Improved goats, aged 2-4 years, after winter kidding, in various stages of lactation. The animals were raised in a free-range system on permanent grassland and were housed at night. Additionally, goats received roughage (hay and clover) and concentrate (ground oats).

Raw milk was high-pressure treated (HP-treated) in the U4040 high-pressure chamber (Unipress Equipment, Warsaw, Poland) within a pressure range of 200-500 $\mathrm{MPa}$ (applied at $100 \mathrm{MPa}$ intervals), at a constant time ( $\mathrm{t}_{\text {const. }}=10 \mathrm{~min}$ ) and constant temperature $\left(\mathrm{T}_{\text {const. }}=20^{\circ} \mathrm{C}\right)$. Caprine milk was skimmed by centrifugation at $2000 \mathrm{rpm}$ in the MPW-351 R centrifuge (MPW Med. Instruments, Warsaw, Poland) for 20 min at a temperature of $20^{\circ} \mathrm{C}$. Analytical samples were prepared according to the diagram in Figure 1. Untreated caprine milk was the control sample. The experiment was conducted in four independent replicates. 


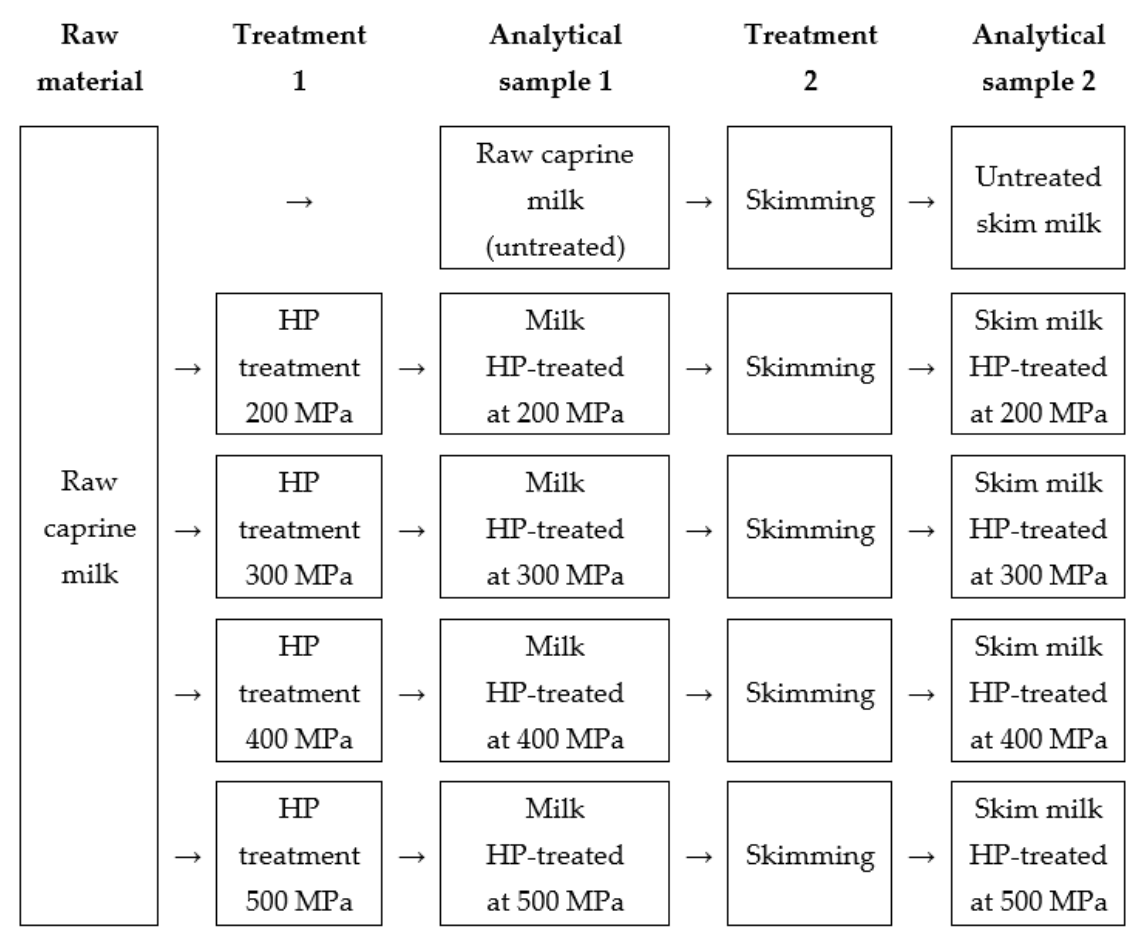

Figure 1. Preparation of analytical samples.

\subsection{Nitrogen Compounds}

Total nitrogen (TN) content and the content of non-casein nitrogen $(\mathrm{NCN})$ and non-protein nitrogen (NPN) in whole and skim milk was determined by the Kjeldahl method [22]. The content of casein $(\mathrm{CN}=(\mathrm{TN}-\mathrm{NCN}) \times 6.38)$ and whey protein $(\mathrm{WP}$ $=(\mathrm{NCN}-\mathrm{NPN}) \times 6.38)$ was determined. The results were expressed as the percentage content of nitrogen compounds (TN, NCN, NPN) and proteins (CN, WP) in whole milk and in skim milk relative to the content of nitrogen compounds and proteins in whole milk, respectively, before the separation of the cream layer.

\subsection{SDS PAGE Electrophoresis}

Proteins were separated in $30 \mu \mathrm{L}$ of polyacrylamide gel (12\% Resolving Gel, Mi niProtean TGX Precast Gels, Biorad, Life Science Group, Warsaw, Poland) in 10-well plates. Fresh samples $(0.1 \mathrm{~mL})$ were diluted with a sample buffer $(0.9 \mathrm{~mL})$ containing $10 \mathrm{mM}$ Tris- $\mathrm{HCl} \mathrm{pH} \mathrm{6.8,} \mathrm{1.0 \%} \mathrm{SDS,} \mathrm{20 \%} \mathrm{glycerol,} 0.02 \%$ bromophenol blue tracking dye, and $50 \mathrm{mM}$ dithiothreitol, and were stored in a freezer. The samples were thawed at room temperature before analysis. The diluted samples in glass vials $(1.5 \mathrm{~mL}$, Bionovo, Eppendorf, Germany) were heated at $100{ }^{\circ} \mathrm{C}$ for $3 \mathrm{~min}$ in a steam chamber. Milk samples of $7 \mu \mathrm{L}$ each were loaded onto SDS-PAGE gel.

Milk proteins were separated by electrophoresis in the Mini-PROTEAN ${ }^{\circledR} 3$ Cell system (BIORAD, Hercules, PA, USA) with Thermo Scientific EC30000XL power supply (Shah Alam, Selangor, Malaysia). Electrophoresis was conducted at $150 \mathrm{~V}$ and $45 \mathrm{~mA}$. Gels were run, stained and destained according to the procedure described by Verdi et al. [23]. Gels were scanned in the DNR LumiBis Bioimaging system (DNR Bio-Imaging Systems Ltd., Neve Yamin, Israel) to obtain the relative protein proportions in each sample. Scanned gels were analyzed in the Totallab program (BIO-RAD Laboratories, Inc., Hercules, CA, USA) to obtain relative protein proportions in each sample.

\subsection{Color Analysis}

Color parameters were measured in CIELAB color space with the CR-400 Chroma Meter (Konica Minolta Sensing Americas, Inc., Ramsey, NJ, USA). Milk samples were placed in Petri dishes. The results were expressed as the total color difference between 
the control sample and HP-treated samples and as the total color difference between untreated and HP-treated skim milk. The following equation was used in the calculations: $\Delta \mathrm{E}=\left(\Delta \mathrm{L}^{2}+\Delta \mathrm{a}^{2}+\Delta \mathrm{b}^{2}\right)^{0.5}$, where $\mathrm{L}^{*}$-lightness from black (0) to white (100), $\mathrm{a}^{*}$-greenness $(-)$ to redness $(+)$, and $b^{*}-$ blueness $(-)$ to yellowness $(+)$.

\subsection{Statistical Analysis}

The effect of pressure $(\mathrm{p})$, skimming $(\mathrm{s})$, and the pressure and skimming $(\mathrm{p} \times \mathrm{s})$ interaction on the analyzed parameters of caprine milk was determined by two-way ANOVA at a significance level of 0.05. Group means were compared in Fisher's LSD test. Data were processed in Statistica v. 13.0 software (StatSoft Inc., Tulsa, OK, USA).

\section{Results and Discussion}

The content of nitrogen compounds in caprine milk (Table 1) was similar to that reported in the literature $[17,18,24]$. Pressure $(p)$ induced significant changes in total nitrogen content $(p<0.05)$, and the content of non-casein nitrogen $(p<0.05)$, casein $(p<0.05)$ and serum proteins $(p<0.05)$ in the analyzed milk samples, but it had no significant effect on the content of non-protein nitrogen. Skimming (s) exerted a significant decrease $(p<0.05)$ in the content of all nitrogen compounds. The pressure and skimming $(p \times s)$ interaction had a significant effect on total nitrogen content $(p<0.05)$, and the content of non-casein nitrogen $(p<0.05)($ Table 1$)$, casein $(p<0.05)$, and serum proteins $(p=0.005)$ (Table 2$)$. Similar to pressure $(\mathrm{p})$, the pressure and skimming $(\mathrm{p} \times \mathrm{s})$ interaction had no significant influence on the content of non-protein nitrogen (Table 1).

Table 1. The effect of high-pressure treatment on the content of nitrogen compounds in whole and skim caprine milk (g/100 g of whole milk).

\begin{tabular}{ccccc}
\hline Milk & & TN & NCN & NPN \\
\hline & $0.1 \mathrm{MPa}$ & & $0.112 \pm 0.001^{\mathrm{a}}$ & $0.034 \pm 0.001^{\mathrm{a}}$ \\
& $200 \mathrm{MPa}$ & & $0.096 \pm 0.001^{\mathrm{c}}$ & $0.034 \pm 0.001^{\mathrm{a}}$ \\
Whole milk & $300 \mathrm{MPa}$ & $0.515 \pm 0.005^{\mathrm{a}}$ & $0.091 \pm 0.003^{\mathrm{d}}$ & $0.034 \pm 0.001^{\mathrm{a}}$ \\
& $400 \mathrm{MPa}$ & & $0.089 \pm 0.004^{\mathrm{d}, \mathrm{e}}$ & $0.034 \pm 0.002^{\mathrm{a}}$ \\
& $500 \mathrm{MPa}$ & & $0.083 \pm 0.003^{\mathrm{f}}$ & $0.034 \pm 0.003^{\mathrm{a}}$ \\
\hline \multirow{5}{*}{ Skim milk } & $0.1 \mathrm{MPa}$ & $0.476 \pm 0.007^{\mathrm{b}}$ & $0.102 \pm 0.002^{\mathrm{b}}$ & $0.033 \pm 0.003^{\mathrm{b}}$ \\
& $200 \mathrm{MPa}$ & $0.426 \pm 0.023^{\mathrm{d}}$ & $0.087 \pm 0.001^{\mathrm{e}}$ & $0.029 \pm 0.001^{\mathrm{b}}$ \\
& $300 \mathrm{MPa}$ & $0.409 \pm 0.001^{\mathrm{e}}$ & $0.084 \pm 0.002^{\mathrm{f}}$ & $0.030 \pm 0.001^{\mathrm{b}}$ \\
& $400 \mathrm{MPa}$ & $0.439 \pm 0.011^{\mathrm{c}, \mathrm{d}}$ & $0.081 \pm 0.001^{\mathrm{f}}$ & $0.030 \pm 0.001^{\mathrm{b}}$ \\
& $500 \mathrm{MPa}$ & $0.447 \pm 0.007^{\mathrm{c}}$ & $0.078 \pm 0.001^{\mathrm{g}}$ & $0.030 \pm 0.001^{\mathrm{b}}$ \\
\hline \multirow{3}{*}{ Significance $(p$ value $)$} & $\mathrm{p}$ & 0.000 & 0.000 & $\mathrm{NS}$ \\
& $\mathrm{s}$ & 0.000 & 0.000 & 0.000 \\
& $\mathrm{p} \times \mathrm{s}$ & 0.000 & 0.000 & $\mathrm{NS}$ \\
\hline
\end{tabular}

Abbreviations: $p$, pressure; $s$, skimming; $\mathrm{p} \times \mathrm{s}$, pressure and skimming interaction; $\mathrm{TN}$, total nitrogen; $\mathrm{NCN}$ non-casein nitrogen; NPN, non-protein nitrogen. Mean values $\pm S D ; n=4$. Values with different superscripts in columns differ significantly at $p<0.05$, depending on the pressure and skimming interaction; in column NPN, mean values with different superscripts differ significantly between whole and skim milk at $p<0.05$; NS-not significant.

In whole milk, HP-treatment induced a significant decrease $(p<0.05)$ in the content of non-casein nitrogen, an increase $(p<0.05)$ in casein levels and a decrease $(p<0.05)$ in whey protein content, but it did not affect $(p \geq 0.05)$ the content of non-protein nitrogen relative to the control sample. A significant decrease $(p<0.05)$ in the concentrations of non-casein nitrogen and whey proteins soluble at $\mathrm{pH} 4.6$ was observed with a rise in pressure. In Fisher's LSD test, the average values of casein content in whole milk subjected to HP-treatment at 200-500 MPa formed a homogeneous group ( $p \geq 0.05)$ (Tables 1 and 2). 
Table 2. The effect of high-pressure treatment on the content of casein and whey protein in whole and skim caprine milk (g/100 g of whole milk).

\begin{tabular}{cccc}
\hline & Milk & CN & WP \\
\hline & $0.1 \mathrm{MPa}$ & $2.571 \pm 0.038^{\mathrm{b}}$ & $0.502 \pm 0.009^{\mathrm{a}}$ \\
& $200 \mathrm{MPa}$ & $2.675 \pm 0.034^{\mathrm{a}}$ & $0.397 \pm 0.008^{\mathrm{c}}$ \\
Whole milk & $300 \mathrm{MPa}$ & $2.706 \pm 0.019^{\mathrm{a}}$ & $0.366 \pm 0.015^{\mathrm{d}}$ \\
& $400 \mathrm{MPa}$ & $2.720 \pm 0.014^{\mathrm{a}}$ & $0.352 \pm 0.017^{\mathrm{d}, \mathrm{e}}$ \\
& $500 \mathrm{MPa}$ & $2.758 \pm 0.019^{\mathrm{a}}$ & $0.314 \pm 0.017^{\mathrm{f}, \mathrm{b}}$ \\
\hline \multirow{3}{*}{ Skim milk } & $0.1 \mathrm{MPa}$ & $2.388 \pm 0.048^{\mathrm{c}}$ & $0.442 \pm 0.015^{\mathrm{b}}$ \\
& $200 \mathrm{MPa}$ & $2.162 \pm 0.137^{\mathrm{e}}$ & $0.369 \pm 0.008^{\mathrm{d}}$ \\
& $300 \mathrm{MPa}$ & $2.074 \pm 0.015^{\mathrm{f}}$ & $0.344 \pm 0.012^{\mathrm{e}}$ \\
& $400 \mathrm{MPa}$ & $2.286 \pm 0.077^{\mathrm{d}}$ & $0.323 \pm 0.008^{\mathrm{f}}$ \\
& $500 \mathrm{MPa}$ & $2.356 \pm 0.052^{\mathrm{c}, \mathrm{d}}$ & $0.304 \pm 0.008^{\mathrm{g}}$ \\
\hline \multirow{3}{*}{ Significance $(p$ value $)$} & $\mathrm{P}$ & 0.000 & 0.000 \\
& $\mathrm{~S}$ & 0.000 & 0.000 \\
& $\mathrm{p} \times \mathrm{s}$ & 0.000 & 0.005 \\
\hline
\end{tabular}

Abbreviations: $\mathrm{p}$, pressure; s, skimming; $\mathrm{p} \times \mathrm{s}$, pressure and skimming interaction; $\mathrm{CN}$, casein; $\mathrm{WP}$, whey protein Mean values $\pm S D ; n=4$. Values with different superscripts in columns differ significantly at $p<0.05$, depending on the pressure and skimming interaction.

The present study revealed that HP-treatment affects the content of nitrogen compounds in caprine milk (Table 2). The observed decrease in whey protein levels suggests that whey proteins are denatured and enter into interactions with casein. HP-induced denaturation of whey proteins leads to loss of their solubility at $\mathrm{pH} 4.6$ after previous interactions with casein in caprine milk [11,20] and in bovine milk [6]. HP-treatment denatures up to $80 \%$ of $\beta$-lactoglobulin in bovine milk $[13,25,26]$ and caprine milk $[11,20]$. According Nassar et al. [27], the degree of whey protein denaturation in caprine milk treated at $500 \mathrm{MPa}$ reached $54.1 \%$ after one day of storage at temperature of $4{ }^{\circ} \mathrm{C}$.

In skim milk obtained from the control sample and from HP-treated samples subjected to different pressure, nitrogen compounds were transferred from whole milk to the cream layer after centrifugation. The above was confirmed by Fisher's LSD test which revealed that the average content of the analyzed nitrogen compounds tended to decrease $(p<0.05)$ in untreated and HP-treated skim milk relative to the corresponding samples of whole milk. The concentration of nitrogen compounds was higher $(p<0.05)$ in untreated skim milk than in HP-treated skim milk. Subject to the applied process parameters, HP-treatment decreased $(p<0.05)$ the content of whey proteins in skim milk with a rise in pressure and decreased total nitrogen content and the content of casein in skim milk which reached minimum values at $300 \mathrm{MPa}(p<0.05)$ (Tables 1 and 2). Liquid-phase whey proteins consist mainly of $\beta$-lactoglobulin, $\alpha$-lactalbumin and, to a smaller extent, serum albumin, immunoglobulins, lactoferrin, transferrin, ferritin, proteose peptone, calmodulin, prolactin and folate-binding protein. Non-protein nitrogen compounds include ammonia, urea, creatinine, creatine, uric acid and amino acids [18].

The decrease in the protein content of milk after centrifugation can probably be attributed to the interactions between milk proteins and emulsion phase components. In a study by Ye et al. [16], $\beta$-lactoglobulin, $\alpha$-lactalbumin and $\kappa$-casein were associated with milk fat globule membranes in cow's milk under exposure to $>100 \mathrm{MPa}, \geq 700 \mathrm{MPa}$ and $\geq 500 \mathrm{MPa}$, respectively.

The effect of HP-treatment on whole milk proteins and protein distribution after the separation of the cream layer was determined by electrophoresis. The protein profile of caprine milk samples is presented in Figure 2. Casein fractions, including $\alpha$-casein $(\alpha-\mathrm{CN}), \beta$-casein $(\beta-\mathrm{CN})$ and $\kappa$-casein $(\kappa-\mathrm{CN})$, and whey proteins, including $\alpha$-lactalbumin $(\alpha$-LA) and $\beta$-lactoglobulin ( $\beta$-LG), were identified and quantified in whole milk and skim milk. The results of electrophoretic separation were used to identify proteins with a molecular weight of $\geq 40 \mathrm{kDa}$, including milk fat globule membrane proteins [28]. 
Electrophoretic bands denoting proteins with a molecular weight of $\geq 40 \mathrm{kDa}$ were less intense in skim milk after cream separation (Figure 2, bands 6-10). Proteins with a molecular weight of $\geq 40 \mathrm{kDa}$ were not quantified. The presence of proteins with a molecular weight higher than that of $\beta$-lactoglobulin and lower than that of $k$-casein was observed in HP-treated milk.
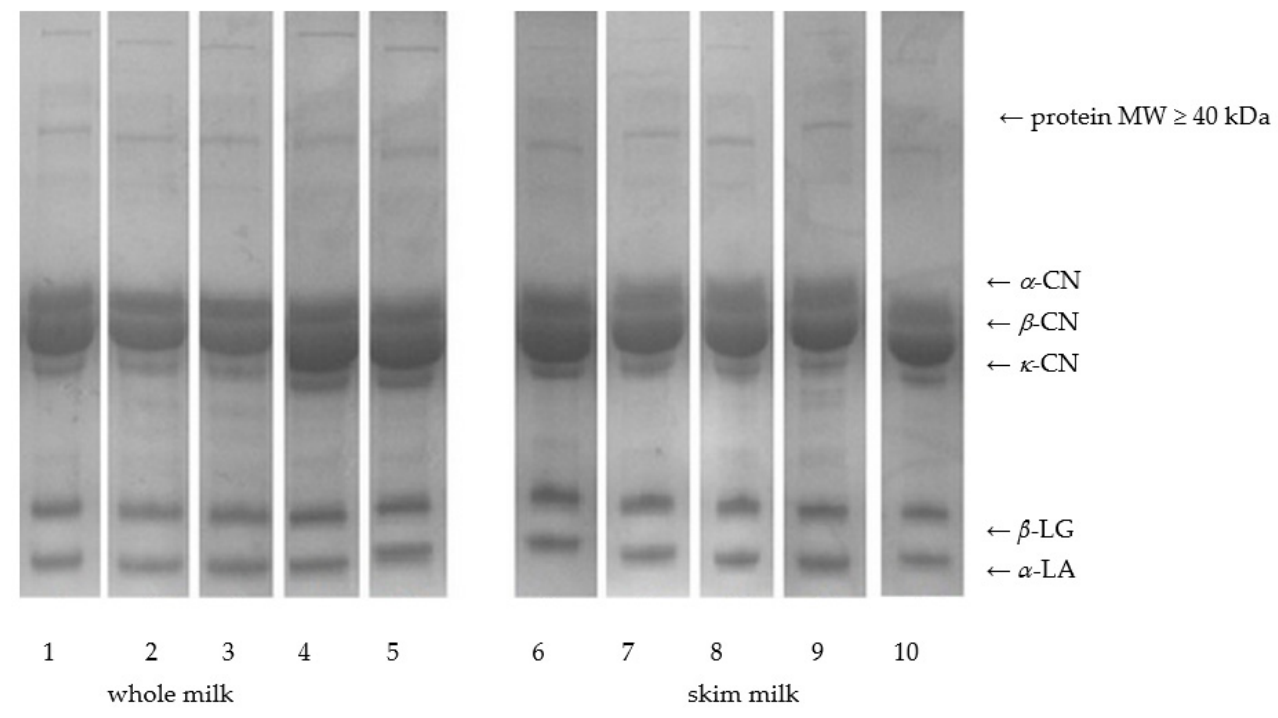

Figure 2. Electrophoresis on polyacrylamide gel (SDS-PAGE) under reducing conditions. Proteins in whole caprine milk: untreated milk (1); HP-treated milk at $p=200 \mathrm{MPa}(2), p=300 \mathrm{MPa}(3), p=400 \mathrm{MPa}$ (4), $p=500 \mathrm{MPa}$ (5). Proteins in skim caprine milk: untreated milk (6); HP-treated milk at $p=200 \mathrm{MPa}(7), p=300 \mathrm{MPa}(8), p=400 \mathrm{MPa}(9), p=500 \mathrm{MPa}(10)$.

The results of densitometric analyses of the protein profile are presented in Table 3. The densitometric quantification of electrophoretic bands in untreated caprine milk revealed the highest content of $\beta-\mathrm{CN}$, whereas the concentrations of the remaining proteins were arranged in the following descending order: $\alpha$-CN $>\beta$-LG $>\kappa-\mathrm{CN} \sim \alpha$-LA (Figure 2 band 1; Table 3). The composition of caprine milk proteins is determined by breed, lactation stage and diet [29,30]. In a study by Abbas et al. [29], the proportions of casein fractions $\alpha_{\mathrm{s} 1}-\mathrm{CN}, \alpha_{\mathrm{s} 2}-\mathrm{CN}, \beta-\mathrm{CN}$ and $\kappa-\mathrm{CN}$ in caprine milk were determined at 1:2:5:2. Casein fractions $\alpha_{\mathrm{s} 1}, \alpha_{\mathrm{s} 2}, \beta+\gamma-\mathrm{CN}$ and $\kappa-\mathrm{CN}$ accounted for 10.4, 14.5, 62 and $13.2 \%$ of total casein in caprine milk, respectively. According to Hejtmankowa et al. [30], caprine milk contains $2.75 \%$ protein, $0.433 \%$ whey protein, and $0.119 \%$ of $\beta$-LG, with an average $\beta$-LG $/ \alpha$-LA ratio of 0.59 .

A quantitative analysis of proteins in HP-treated whole milk also revealed the highest concentration of $\beta-\mathrm{CN}$, smaller amounts of $\alpha-\mathrm{CN}$, and the lowest content of $\kappa-\mathrm{CN}$ (Table 3). The results of two-way ANOVA indicate that pressure (p), skimming (s), and the pressure and skimming $(\mathrm{p} \times \mathrm{s})$ interaction did not influence the content of $\alpha$-CN, $\beta$-CN, $\kappa-\mathrm{CN}, \alpha$-LA and $\beta$-LG ( $p \geq 0.05)$. Two-way ANOVA revealed that the casein to whey protein ratio was significantly $(p<0.05)$ influenced by pressure (p). Skimming (s) and the pressure and skimming interaction $(\mathrm{p} \times \mathrm{s})$ had no effect on the casein to whey protein ratio. The casein to whey protein ratio was higher in milk treated at $500 \mathrm{MPa}$ than in untreated milk and milk subjected to 200-400 MPa. A similar relationship was observed in skim milk obtained from whole untreated milk and in skim milk obtained from pressurized whole milk. Skimming $(\mathrm{s})$ and the pressure and skimming interaction $(\mathrm{p} \times \mathrm{s})$ did not exert a significant influence on the casein to whey protein ratio (Table 4). 
Table 3. The effect of high-pressure treatment on the content of $\alpha$-casein $(\alpha-\mathrm{CN}), \beta$-casein $(\beta$-CN), $\kappa$-casein $(\kappa$-CN), $\beta$-lactoglobulin ( $\beta$-LG) and $\alpha$-lactalbumin $(\alpha$-LA) in whole and skim caprine milk (g/100 g of protein).

\begin{tabular}{ccccccc}
\hline Milk & & $\alpha$-CN & $\beta$-CN & $\kappa$-CN & $\beta$-LG & $\alpha$-LA \\
\hline & $0.1 \mathrm{MPa}$ & $24.85 \pm 0.59$ & $34.68 \pm 1.44$ & $13.07 \pm 0.99$ & $14.40 \pm 1.49$ & $13.00 \pm 0.27$ \\
& $200 \mathrm{MPa}$ & $24.81 \pm 0.65$ & $34.41 \pm 1.19$ & $12.47 \pm 1.28$ & $14.81 \pm 1.05$ & $13.49 \pm 0.50$ \\
Whole milk & $300 \mathrm{MPa}$ & $24.85 \pm 0.63$ & $34.23 \pm 2.31$ & $12.72 \pm 0.60$ & $14.60 \pm 0.56$ & $13.60 \pm 0.82$ \\
& $400 \mathrm{MPa}$ & $24.79 \pm 0.92$ & $34.38 \pm 2.33$ & $12.82 \pm 1.23$ & $14.39 \pm 0.64$ & $13.62 \pm 0.55$ \\
& $500 \mathrm{MPa}$ & $24.74 \pm 1.41$ & $36.21 \pm 3.27$ & $12.61 \pm 1.04$ & $13.67 \pm 1.48$ & $12.77 \pm 1.15$ \\
\hline \multirow{5}{*}{ Skim milk } & $0.1 \mathrm{MPa}$ & $24.70 \pm 2.22$ & $32.66 \pm 1.73$ & $12.86 \pm 0.58$ & $15.96 \pm 0.46$ & $13.82 \pm 0.67$ \\
& $200 \mathrm{MPa}$ & $23.83 \pm 0.22$ & $34.02 \pm 0.80$ & $12.81 \pm 0.66$ & $15.47 \pm 1.27$ & $13.88 \pm 0.59$ \\
& $300 \mathrm{MPa}$ & $24.22 \pm 0.46$ & $34.88 \pm 0.80$ & $12.40 \pm 0.96$ & $15.04 \pm 0.79$ & $13.45 \pm 0.89$ \\
& $400 \mathrm{MPa}$ & $24.68 \pm 1.07$ & $34.25 \pm 0.76$ & $12.41 \pm 0.82$ & $14.80 \pm 0.44$ & $13.86 \pm 0.77$ \\
& $500 \mathrm{MPa}$ & $26.35 \pm 0.84$ & $35.84 \pm 0.88$ & $11.48 \pm 0.83$ & $13.41 \pm 0.98$ & $12.92 \pm 0.85$ \\
\hline \multirow{5}{*}{ Significance $(p$ value) } & $\mathrm{P}$ & $\mathrm{NS}$ & $\mathrm{NS}$ & $\mathrm{NS}$ & $\mathrm{NS}$ & $\mathrm{NS}$ \\
& $\mathrm{S}$ & $\mathrm{NS}$ & $\mathrm{NS}$ & $\mathrm{NS}$ & $\mathrm{NS}$ \\
& $\mathrm{p} \times \mathrm{s}$ & $\mathrm{NS}$ & $\mathrm{NS}$ & $\mathrm{NS}$ & $\mathrm{NS}$ & $\mathrm{NS}$ \\
\hline
\end{tabular}

Abbreviations: $\mathrm{p}$, pressure; s, skimming; $\mathrm{p} \times \mathrm{s}$, pressure and skimming interaction; NS—not significant. Mean values $\pm S D ; n=4$.

Table 4. The effect of high-pressure treatment on the content of casein $(\mathrm{CN})$, whey protein (WP) and the CN:WP ratio in whole and skim caprine milk (g/100 g of protein).

\begin{tabular}{|c|c|c|c|c|}
\hline \multicolumn{2}{|c|}{ Milk } & \multirow{2}{*}{$\begin{array}{c}\mathrm{CN}(\alpha-+\beta-+\kappa-\mathrm{CN}) \\
72.60 \pm 1.67^{\mathrm{a}}\end{array}$} & \multirow{2}{*}{$\begin{array}{c}\text { WP }(\beta \text {-LG }+\alpha \text {-LA }) \\
27.40 \pm 1.67^{\mathrm{a}}\end{array}$} & \multirow{2}{*}{$\begin{array}{c}\mathrm{CN}: \mathbf{W P} \\
2.66 \pm 0.22^{\mathrm{b}}\end{array}$} \\
\hline \multirow{5}{*}{ Whole milk } & $0.1 \mathrm{MPa}$ & & & \\
\hline & $200 \mathrm{MPa}$ & $71.70 \pm 0.55^{\mathrm{a}}$ & $28.30 \pm 0.55^{\mathrm{a}}$ & $2.53 \pm 0.07^{b}$ \\
\hline & $300 \mathrm{MPa}$ & $71.80 \pm 1.08^{a}$ & $28.20 \pm 1.08^{\mathrm{a}}$ & $2.55 \pm 0.14^{b}$ \\
\hline & $400 \mathrm{MPa}$ & $71.99 \pm 0.37^{\mathrm{a}}$ & $28.01 \pm 0.37^{\mathrm{a}}$ & $2.57 \pm 0.05^{b}$ \\
\hline & $500 \mathrm{MPa}$ & $73.56 \pm 2.45^{b}$ & $26.44 \pm 2.45^{b}$ & $2.80 \pm 0.36^{a}$ \\
\hline \multirow{5}{*}{ Skim milk } & $0.1 \mathrm{MPa}$ & $70.22 \pm 1.02^{a}$ & $29.78 \pm 1.02^{a}$ & $2.36 \pm 0.12^{b}$ \\
\hline & $200 \mathrm{MPa}$ & $70.65 \pm 1.06^{\mathrm{a}}$ & $29.35 \pm 1.06^{\mathrm{a}}$ & $2.41 \pm 0.12^{b}$ \\
\hline & $300 \mathrm{MPa}$ & $71.50 \pm 0.81^{\mathrm{a}}$ & $28.50 \pm 0.81^{\mathrm{a}}$ & $2.51 \pm 0.10^{b}$ \\
\hline & $400 \mathrm{MPa}$ & $71.34 \pm 1.07^{\mathrm{a}}$ & $28.66 \pm 1.07^{\mathrm{a}}$ & $2.49 \pm 0.13^{b}$ \\
\hline & $500 \mathrm{MPa}$ & $73.67 \pm 0.82^{b}$ & $26.33 \pm 0.82^{b}$ & $2.80 \pm 0.12^{a}$ \\
\hline \multirow{3}{*}{ Significance ( $p$ value) } & $\mathrm{P}$ & 0.018 & 0.018 & 0.017 \\
\hline & $S$ & NS & NS & NS \\
\hline & $\mathrm{p} \times \mathrm{s}$ & NS & NS & NS \\
\hline
\end{tabular}

Abbreviations: $\mathrm{p}$, pressure; s, skimming; $\mathrm{p} \times \mathrm{s}$, pressure and skimming interaction. Mean values $\pm \mathrm{SD} ; \mathrm{n}=4$. Values with different superscripts in the $\mathrm{CN}$ column, WP column and the CN:WP column differ significantly at $p<0.05$, depending on the applied pressure; NS-not significant.

The results of electrophoresis performed under reducing conditions revealed that $\mathrm{HP}$-treatment at $\leq 400 \mathrm{MPa}$ did not affect the content of casein fractions $(\alpha, \beta$ and $\kappa)$, $\alpha$-lactalbumin, $\beta$-lactoglobulin (Table 3) or the casein to whey protein ratio (Table 4). The protein content of HP-treated milk decreased after skimming (Table 2), but the proportions of the analyzed milk proteins remained unchanged (Table 3). In the present study, the protein profile determined by electrophoretic separation did not support the identification of proteins that interacted with the milk fat globule membrane.

Pressure (p), skimming (s) and the pressure and skimming $(\mathrm{p} \times \mathrm{s})$ interaction significantly $(p<0.05)$ influenced the total color difference $\Delta \mathrm{E}$ between whole and skim milk. The values of $\Delta E$ increased with a rise in pressure (Figure 3). The pressure-induced changes in color of whole milk, increasing with a rise in pressure, were reported by Gervilla et al. [31] and Kiełczewska et. al. [32]. 


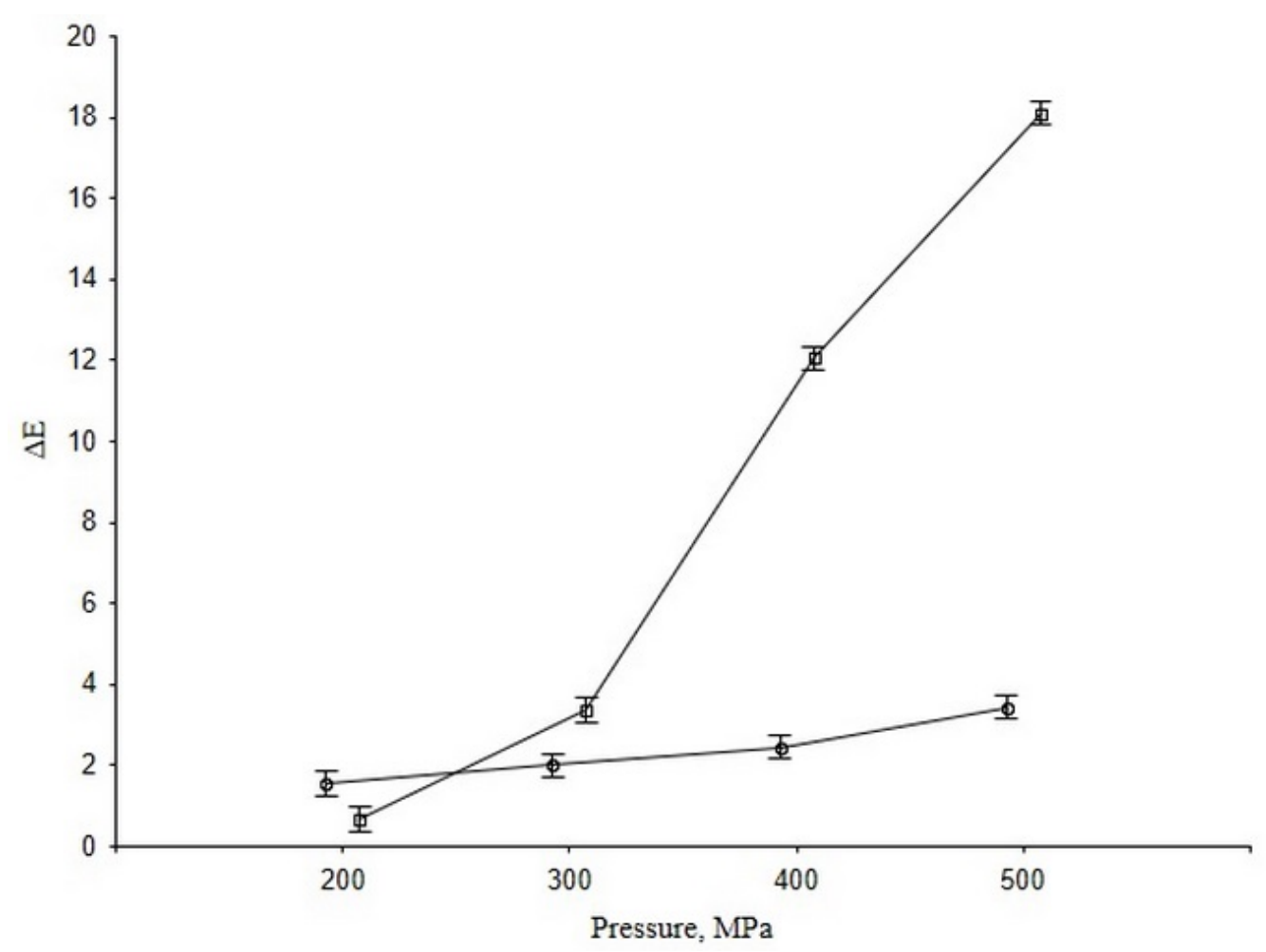

Figure 3. The effect of high-pressure treatment on the total color difference $\Delta \mathrm{E}$ in whole milk (open circle) and skim milk (open square). Vertical bars denote 0.95 confidence intervals. Significance: pressure effect at $p<0.05$; skimming effect at $p<0.05$; interaction effect of pressure and skimming at $p<0.05$.

The values of $\Delta \mathrm{E}$ were lower in skim milk HP-treated at $200 \mathrm{MPa}$ than in the corresponding sample of whole milk. The highest values of $\Delta \mathrm{E}$ were noted in skim milk obtained from milk HP-treated at $\geq 300 \mathrm{MPa}$ (Figure 3 ). $\Delta \mathrm{E}$ values were higher in skim milk than in whole milk HP-treated at $\geq 300 \mathrm{MPa}$, which indicates that differences in color resulted mainly from changes in colloidal phase components.

Changes in the color of milk can be attributed to the modification of colloidal and emulsion phase components, namely changes in the size of casein micelles that undergo disaggregation and aggregation [33], as well as changes in the number and size of milk fat globules and their aggregates [34]. The increase in the total color difference of HPtreated skim milk was indicative of changes in the colloidal milk phase, in particular under exposure to $\geq 300 \mathrm{MPa}$. The main caprine milk proteins are casein and its fractions: $\alpha$ s1-casein $\alpha$ s2-casein, $\beta$-casein and $k$-casein, which, together with colloidal calcium phosphates, are the structural components of casein micelles. Literature data partly explain the influence of HP-treatment at $\geq 300 \mathrm{MPa}$ on the total color difference in skim caprine milk. According to research, the decrease in the lightness of HP-treated milk resulted mainly from changes in the size of protein molecules and casein disaggregation into submicelles at $<150 \mathrm{MPa}[4,5]$. HP-treatment ( $>100 \mathrm{MPa}$ ) increased casein solubility $[9,14,25,26]$ and induced changes in the size of casein micelles which are influenced by process parameters $[5,12]$. The disintegration of casein micelles and an increase in the solubility of different fractions (e.g., $\beta$-casein) is determined by the number of phosphoseryl residues, and it is influenced by the dissociation of colloidal calcium phosphate and the weakening of hydrophobic interactions. Subject to the applied pressure, HP-treatment decreases the size of casein micelles (200 MPa), induces differences in the size of casein micelles due to their fragmentation and the re-aggregation of subunits, promotes hydrophobic interactions that lead to the formation of micelles larger than the native micelles (250 MPa), and decreases the size of casein micelles $(\geq 300 \mathrm{MPa})$, in particular under exposure to lower temperature $[9,12,14]$. 
Pressure-induced changes in the composition and processing suitability of caprine milk proteins exert a significant influence on the properties of dairy products. Changes in protein structure, including pressure-induced denaturation of whey proteins, and the formation of whey protein and casein aggregates, influence the functional attributes of proteins, such as the ability to stabilize emulsions, bind water and form gels. Proteins determine the properties of both raw milk and dairy products; therefore, pressure-induced changes in protein structure are an important consideration in industrial processes. These changes are particularly important in the production of emulsions, ripened cheese, cottage cheese and fermented milk products (such as yogurt), where the chemical, functional and nutritional properties of proteins play a pivotal role [1-5].

\section{Conclusions}

High-pressure treatment exerted a varied influence on the content of nitrogen compounds, excluding non-protein nitrogen. HP-treatment decreased the content of whey proteins soluble at $\mathrm{pH} 4.6$, which could be attributed to their denaturation and interactions with casein. HP-treatment promotes the formation of proteins with a molecular weight higher than that of $\beta$-lactoglobulin and lower than that of casein. Despite the above, HP-treatment did not affect the percentage content of $\alpha-\mathrm{CN}, \beta-\mathrm{CN}, \mathrm{k}-\mathrm{CN}, \beta-\mathrm{LG}$ or $\alpha$-LA in total protein. The observed changes in the dynamic equilibrium of HP-treated proteins can affect the processing suitability of caprine milk. Skimming decreased the content of nitrogen compounds in the control sample, and the resulting decrease was more pronounced in HP-treated samples. In HP-treated milk, skimming did not induce changes in the proportions of casein fractions or whey protein (relative to the corresponding samples of whole milk), despite a decrease in the content of all nitrogen compounds after the separation of the cream layer. HP treatment induced changes in colour in milk. Total color difference in milk increased with pressure, especially in skim milk. Skimming induced changes in milk color relative to the corresponding samples of whole milk. Changes in the values of total color difference in milk were result of the modification of the colloidal phases, mainly change in size of casein micelles. Further research is needed to determine the nature of interactions between proteins and modification of proteins' structure in HP-treated caprine milk. The presented results may be useful in designing new processing lines, which is an important consideration in view of the growing interest in the diversification of raw materials in the dairy industry.

Author Contributions: Conceptualization: A.J., K.K.; methodology, K.K., J.K.; validation, A.D., M.W.; investigation, A.D., K.K., J.K.; data curation, A.J., K.K.; writing—original draft preparation, A.J., K.K., M.W.; writing-review and editing, A.D., A.J., K.K., J.K.; visualization, A.D., J.K.; supervision, A.J., K.K., M.W.; project administration, A.D., A.J., K.K.; funding acquisition, J.K., K.K. All authors have read and agreed to the published version of the manuscript.

Funding: Project financially supported by Minister of Science and Higher Education in the range of the program entitled "Regional Initiative of Excellence" for the years 2019-2022, Project No. 010/RID/2018/19, amount of funding 12.000.000 PLN.

Institutional Review Board Statement: Not applicable.

Informed Consent Statement: Not applicable.

Data Availability Statement: Not applicable.

Acknowledgments: The authors would like to thank Anna Brakoniecka and Roman Łaszek for technical assistance during the study.

Conflicts of Interest: Authors declare no conflicts of interest. 


\section{References}

1. Considine, T.; Patel, H.A.; Anema, S.G.; Singh, H.; Creamer, L.K. Interaction of milk proteins during heat and high hydrostatic pressure treatments-A review. Innov. Food Sci. Emerg. Technol. 2007, 8, 1-23. [CrossRef]

2. Datta, N.; Deeth, H.C. High-pressure processing. In Encyclopedia of Dairy Sciences; Roginski, H., Fuquay, J.W., Fox, P.F., Eds.; Academic Press: London, UK, 2003; pp. 1327-1333.

3. Lopez-Fandino., R. High pressure-induced changes in milk proteins and possible applications in dairy technology. Int. Dairy J. 2006, 16, 1119-1131. [CrossRef]

4. Messens, W.; Van Camp, J.; Dewettinck, K. High pressure processing to improve dairy quality. In Dairy Processing. Improving Quality; Smit, G., Ed.; Woodhead Publishing Ltd.: Cambridge, UK; CRC Press: Boca Raton, FL, USA, 2003; pp. $310-328$.

5. Trujillo, A.J.; Capellas, M.; Saldo, J.; Gervilla, R.; Guamis, B. Applications of high-hydrostatic pressure on milk and dairy products: A review. Innov. Food Sci. Emerg. Technol. 2002, 3, 295-307. [CrossRef]

6. Huppertz, T.; Fox, P.F.; Kelly, A.L. High pressure treatment of bovine milk: Effect on casein micelles and whey proteins. J. Dairy Res. 2004, 71, 97-106. [CrossRef]

7. Huppertz, T.; Fox, P.F.; Kelly, A.L. High pressure-induced denaturation of $\alpha$-lactalbumin i $\beta$-lactoglobulin in bovine milk and whey: A possible mechanism. J. Dairy Res. 2004, 71, 489-495. [CrossRef] [PubMed]

8. Goyal, A.; Sharma, V.; Upadhyay, N.; Sihag, M.; Kaushik, R. High pressure processing and its impact on milk proteins: A review. J. Dairy Technol. 2013, 2, 2319-3409.

9. Anema, S.G.; Lowe, E.K.; Stockmann, R. Particle size changes and casein solubilisation in high-pressure-treated skim milk. Food Hydrocoll. 2005, 19, 257-267. [CrossRef]

10. Huppertz, T.; Fox, P.F.; Kelly, A.L. Properties of casein micelles in high pressure-treated bovine milk. Food Chem. 2004, 87, 103-110. [CrossRef]

11. Law, A.J.R.; Leaver, J.; Felipe, X.; Ferragut, V.; Pla, R.; Guamis, B. Comparison of the effects of high pressure and thermal treatments on the casein micelles in goat's milk. J. Agric. Food Chem. 1998, 46, 2523-2530. [CrossRef]

12. Orlien, V.; Knudsen, J.C.; Colon, M.; Skibsted, L.H. Dynamics of casein micelles in skim milk during and after high pressure treatment. Food Chem. 2006, 98, 513-521. [CrossRef]

13. Lopez-Fandino, R.; De la Fuente, M.A.; Ramos, M.; Olano, A. Distribution of minerals and proteins between the soluble and colloidal phases of pasteurized milks from different species. J. Dairy Res. 1998, 65, 69-78. [CrossRef]

14. Regnault, S.; Thiebaud, M.; Dumay, E.; Cheftel, J.C. Pressurisation of raw skim milk and of a dispersion of phosphocaseinate at $9{ }^{\circ} \mathrm{C}$ or $20^{\circ} \mathrm{C}$ : Effects on the distribution of minerals and proteins between colloidal and soluble phases. J. Dairy Res. 2006, 73, 91-100. [CrossRef] [PubMed]

15. Patel, H.A.; Singh, H.; Anema, S.G.; Creamer, L.K. Effects of heat and high hydrostatic pressure treatments on disulfide bonding interchanges among the proteins in skim milk. J. Agric. Food Chem. 2006, 54, 3409-3420. [CrossRef] [PubMed]

16. Ye, A.; Anema, S.G.; Singh, H. High-pressure-induced interactions between milk fat globule membrane proteins and skim milk proteins in whole milk. J. Dairy Sci. 2004, 87, 4013-4022. [CrossRef]

17. Barłowska, J.; Szajkowska, M.; Litwińczuk, Z.; Król, J. Nutritional value and technological suitability of milk from various animal species used for dairy production. Compr. Rev. Food Sci. F. 2011, 10, 291-301. [CrossRef]

18. Park, Y.W.; Juarez, M.; Ramos, M.; Haenlein, G.F.W. Physico-chemical characteristics of goat and sheep milk. Small Rum. Res. 2007, 68, 88-113. [CrossRef]

19. Ruprichová, L.; Tompa, G.; Králová, M.; Borkovcová, I.; Bedáňová, I.; Vorlová, L. Profiling of caseins in cows', goats' and ewes' milk and dairy products by reversed-phase high-performance liquid chromatography. J. Food Nutr. Res. 2015, 54, 218-228.

20. Felipe, X.; Capellas, M.; Law, A.J.R. Comparison of the effects of high-pressure treatments and heat pasteurization on the whey proteins in goat's milk. J. Agric. Food Chem. 1997, 45, 627-631. [CrossRef]

21. Lopez-Fandino, R.; Olano, A. Cheese-making properties of ovine and caprine milks submitted to high pressures. Le Lait 1998, 78, 341-350. [CrossRef]

22. AOAC. Official Methods of Analysis of AOAC International, 18th ed.; AOAC International: Gaithersburg, MD, USA, 2007.

23. Verdi, R.J.; Barbano, D.M.; Dellavalle, M.E.; Senyk, G.F. Variability in true protein, casein, nonprotein nitrogen, and proteolysis in high and low somatic cell count milks. J. Dairy Sci. 1987, 70, 230-242. [CrossRef]

24. Olalla, M.; Ruiz-López, M.D.; Navarro, M.; Artacho, R.; Cabrera, C.; Giménez, R.; Rodriguez, C.; Mingorance, R. Nitrogen fractions of Andalusian goat milk compared to similar types of commercial milk. Food Chem. 2009, 113, 835-838. [CrossRef]

25. Bravo, F.I.; Molina, E.; Lopez-Fandino, R. Effect of the high-pressure-release phase on the protein composition of the soluble milk fraction. J. Dairy Sci. 2012, 95, 6293-6299. [CrossRef] [PubMed]

26. Bravo, F.I.; Felipe, X.; Lopez-Fandino, R.; Molina, E. High-pressure treatment of milk in industrial and pilot-scale equipments: Effect of the treatment conditions on the protein distribution in different milk fractions. Eur. Food Res. Technol. 2013, 236, 499-506. [CrossRef]

27. Nassar, K.S.; Zhang, S.; Lu, J.; Pang, X.; Ragab, E.S.; Yue, Y.; Lv, J. Combined effects of high-pressure treatment and storage temperature on the physicochemical properties of caprine milk. Int. Dairy J. 2019, 96, 66-72. [CrossRef]

28. Smoczyński, M.; Staniewski, B.; Kiełczewska, K. Composition and structure of the bovine milkfat globule membrane-some nutritional and technological implications. Food Rev. Int. 2012, 28, 188-202. [CrossRef] 
29. Abbas, H.M.; Hassan, F.A.M.; Abd El-Gawad, M.A.M.; Enab, A.K. Physicochemical characteristics of goat's milk. Life Sci. J. 2014, 11,307-317. Available online: http:/ / www.lifesciencesite.com (accessed on 28 March 2021).

30. Hejtmankova, A.; Pivec, V.; Trnkova, E.; Dragounova, H. Differences in the composition of total and whey proteins in goat and ewe milk and their changes throughout the lactation period. Czech. J. Anim. Sci. 2012, 57, 323-331. [CrossRef]

31. Gervilla, R.; Ferragut, V.; Guamis, B. High hydrostatic pressure effects on colour and milk-fat globule of ewe's milk. J. Food Sci. 2001, 66, 880-885. [CrossRef]

32. Kiełczewska, K.; Jankowska, A.; Dabrowska, A.; Wachowska, M.; Ziajka, J. The effect of high pressure treatment on the dispersion of fat globules and the fatty acid profile of caprine milk. Int. Dairy J. 2020, 102, 104607. [CrossRef]

33. Pereda, J.; Ferragut, V.; Quevedo, J.M.; Guamis, B.; Trujillo, A.J. Effects of ultra-high pressure homogenisation on microbial and physicochemical shelf life of milk. J. Dairy Sci. 2007, 90, 1081-1093. [CrossRef]

34. Amador-Espejo, G.G.; Suàrez-Berencia, A.; Juan, B.; Bárcenas, M.E.; Trujillo, A.J. Effect of moderate inlet temperatures in ultrahigh-pressure homogenisation treatments on physicochemical and sensory characteristics of milk. J. Dairy Sci. 2014, 97, 659-671. [CrossRef] [PubMed] 